\title{
Psychological Analysis of Fatih's Character-Building in Egosentris: A Novel by Syahid Muhammad
}

\author{
Mutia Sari Nursafira ${ }^{1}$, Wella Cisilya Putri ${ }^{2}$, Sandra Yunira ${ }^{3}$, Nelia Gari ${ }^{4}$, and Budianto Hamuddin ${ }^{3}$ \\ ${ }_{1,2,3,4}$ U-RAISE Academy, Pekanbaru, Indonesia \\ ${ }^{5}$ Universitas Lancang Kuning, Pekanbaru, Indonesia \\ budihamuddin@gmail.com
}

\begin{abstract}
ARTICLE HISTORY
Received : 26 April 2019

Revised : 18 May 2019

Accepted : 27 August 2019
\end{abstract}

\section{KEYWORDS}

Psychoanalytic

Characterisation

Psychological Conflict

Egosentris

Literature Analysis

\begin{abstract}
As current era necessitates access to information technology, people of all ages are exposed to the prevalent online hate speech. This literature analysis aims to analyse the psychological characterisation of Fatih, one of the characters in Syahid Muhammad's novel Egosentris, to address how current social media interactions negatively affects one's mental health. This article described characterisation and psychological conflict using the literary psychology approach based on Sigmund Freud's psychoanalytic theory, in line with the characterisation theory proposed by Nurgiyantoro (2007). Psychoanalytic theory is a staple theory of human personality that is often used in the world of literature, which is divided into three structures of human nature, i.e., id, ego, and superego. The analysis involved several steps, such as categorisation, tabulation, interpretation, inference, and validity of the data. The results of the study revealed that Fatih's personality in the Egosentris novel is kind, honest, sensitive, critical, and caring. Though in some situations, Fatih's character was found to employ some negative characters such as being stubborn, spiteful and bad-tempered. This present article also found the psychological conflict experienced by Fatih includes emotions such as anger, anxiety, fear, regret, pressure, and resentment. These kinds of psychological conflict have changed his personality to be an inclusive person. The study reflects the outcomes of psychological analysis on Fatih's character to raise public awareness about regarding importance of noticing people's mental health and to diminish the spread of hate comments and harmful speech to others.
\end{abstract}

\section{Introduction}

Literary works are the results of imagination and the form of one's thoughts that are poured in such a way, and it is also meaningful for anyone who reads it. Concerning the type, literary works can be divided into prose (fiction), poetry and drama. From the three types of literature, the author only focuses on fiction prose. In literature, especially novels, there are several important elements can be determined whether the work is good or not; one of them is characterization. Characterization is how the author describes the characters, so the reader knows about the character's traits and personality (Siswandarti, 2009).

Here, characterization has greatly influenced the content of the story, as what the readers can value how the writer develops the characters in every incident in the story. Whether the writer succeeds in creating a strong character or even looks unattractive to the readers because it is considered unreasonable, when it talks about character figures, it just has the power to control the whole story in a novel. The writer can bring the character to get through many hurdles and problems in various situations. Not only that, the character can be used as a bridge for the writer to convey messages and also give rise to reactions from readers either happy or sad.
In literature, there is a study called literary psychology. Literary psychology can be used as a way to enjoy a literary work. Literary psychology is a study that sees literature as a psychological activity (Endaswara, 2011). There are three ways to understand the relationship between psychology and literature, namely studying the psychology of the author as a writer, studying the psychology of the fictional characters and studying the psychology of the readers. (Ratna, 2009). Therefore this study seen literary psychology can be put as a study that focused on the psychology of the characters in the literature, the authors who created the work, even the audience of literary works. In analyzing the psychology of the characters in this novel, the author uses a literary psychology approach to describe the character Fatih in the novel Egosentris written by Syahid Muhammad. This descriptive analysis-based study uses two theories, psychoanalysis theory by Sigmund Freud and characterization theory by Nurgiyantoro.

In psychoanalytic theory, Freud (1923) divides the structure of human personality into three sorts. There are id, ego, and superego. Meanwhile, the characterization theory by Nurgiyantoro will discuss Fatih's character. Whether he is the main character (protagonist or antagonist), additional 
figure, simple character, round figure, static figure, developing character, typical character or neutral figure.

Talking about the novel which is going to be analyzed, Egosentris is a novel by the writer Syahid Muhammad and published in March 2018. Egosentris is Syahid's first solo novel after successfully published two previous novels he wrote with Stefani Bella. If looking at Kamus Besar Bahasa Indonesia (KBBI), the word Egosentris means making yourself as the centre of thought (deeds); self-centred (value everything from the point of yourself). This novel brings a dramatic social theme that has an impact on human personality and mental health. Besides, Syahid Muhammad, as the author of Egosentris, presents a number of beautiful poems and prose full of meanings also implied by hidden messages. Egosentris tells about three psychology students who have their own problems.

Moreover, there are Saka whose good attitude to everyone is always misunderstood, Fana whose life is overseen by her parents all the time and she has spiritual abilities inherited from her grandmother and Fatih who is critical in commenting on what makes him disturbed so often which becomes fun jokes by his college friends (Goodreads, 2018). These characters are the reason why the author wants to analyze this novel. Of the three main characters, Fatih is the one going to be discussed in this paper. His strong character and the background of his life affect his attitude in interacting with people around are very clearly related to mental health issues. Furthermore, Fatih, who is have been known for being critical, has a habit of putting his right hand in his left armpit when he feels stressed or insecure. But not just that, at the end of the novel, it turned out surprisingly, Fatih had also committed self-harm secretly since the death of his father. He kept his own sadness, he often locked himself in the room and even playing with a razor blade to slash the lower part of his left armpit. All problems came to Fatih were making him very depressed and getting hurt.

Fatih also wanted to end his life on Mount Prau after he had recorded his voice of outpouring, his anxiety, and goodbye through his walkman which was accidentally discovered by Saka and Fana in his room. Luckily at the end of the story, Fatih was saved even though he had to be hospitalized. Also, what makes the writer interested in discussing it is Egosentris also describes the reality of the present. When it viewed from today's reality and linked to the topic raised by the Egosentris novel, citizen's awareness about mental health is low as time goes by. People assume that mental health issues are still taboo for discussion at this time. However, out there, many people sustain it, yet they don't realize it. Most of the trigger factors come from their own environment, whether it is bullying, violence, and so on. Quite a few of them are stressed, depressed, and others choose to end their lives by self-injury to suicide. The World Health Organisation (WHO) has stated in 2015 that suicide was the second-highest cause of death in the world in the age range of 15-29 years. This case implies, they chose suicide as the only way to end the suffering they felt.

Moreover, Syahid Muhammad is also touched on the negative side of using social media in real life. Sometimes, a person only uses social media as a show-off and only point out their happiest life as if other people think they don't have any problem at all. And the most worrying thing is the using of social media as a weapon to fight those who do not necessarily have an iron will in facing several scathing comments. Hopefully, this paper can make people aware that mental awareness is essential and more care about around the others without having to become a judgmental person.

\section{Method}

In this study, the author uses a literary psychology approach to define Fatih's character in the novel Egosentris written by Syahid Muhammad. Analysis based on this descriptive analysis of characterization uses two theories, namely psychoanalysis Sigmund Freud and the characterization theory of Nurgiyantoro to add a more comprehensive explanation. In the analysis process, it takes numerous steps to collect data such as categorizing, tabulating, interpreting, inference and validating data. Categorization is a grouping or sorting data based on predetermined categories according to the purpose of the analysis, character figures and psychological conflicts which is experienced by Fatih in the novel Egosentris. Tabulation is the presentation of data in the form of a summary table that shows an indication of the problem under this analysis. Interpretation is made using the literary psychology approach using Sigmund Freud's psychoanalytic theory and the characterization theory of Nurgiyantoro. The inference is the last step in data analysis activities. This data will be more comfortable by translating it from Indonesian into English. The next step is to make conclusions based on the results of the analysis and discussion. The validity of the data in this analysis is carried out through to read the novel repetitively; the previous data obtained becomes consistent.

\section{Results and Discussion}

The characterization is one of the intrinsic elements, which is the primary analysis for this paper. The character who is portrayed by the writer directly or indirectly (Sehandi, 2014). It refers to the traits and attitude of the characters. Figures or characters can be displayed by the writer in an outward and inward form. In the inner form, it can be described from the view of his life, his behaviour, attitude, beliefs, etc. (Sehandi, 2014).

Based on its characters and the development of conflicts might affect the characters' personality is unique to be analyzed. In a literary work, it will discuss the psychology literary, which is a combination of science between literature and psychology. Literary psychology can be divided into three approaches. There is the textual 
approach, interpreted as studying the psychology of the characters in the story. Next, is a receptive-pragmatic approach that studies the psychology of the readers and finally, the expressive approach that examines the author of literature (Roekhan, 1990).

Through the psychology literary approach, the author wants to analyze the psychology of the characters in the novel Egosentris by using Sigmund Freud's psychoanalytic theory (1856-1939) which is a theory that is often used as a study to analyze the psychological elements of the characters in literary works. Psychoanalytic theory is divided into three structures of human personality, namely $i d$, ego, and superego. The id is the most basic structure of human nature and has existed since human birth. From this $i d$, the ego and superego will appear. The ego develops from the $i d$, which is a psychological aspect of personality and arises from awareness and decision making on human behaviour. For the last is superego that grows from the human ego. Superego reflects social values and makes individuals aware of moral demands.

The character of Fatih in the Egosentris novel is described by the author through speech, behaviour and the way he interacts with other characters through the narrative and dialogue section. The characteristics of Fatih in the Egosentris novel includes being kind, honest, sensitive, critical and caring. Still, in some situations, Fatih's character has 'negative' characteristics such as stubbornness, vindictive, and bad-tempered.

Table 1. Fatih's Characteristics

\begin{tabular}{lcc}
\hline Characteristics & $\begin{array}{c}\text { Personality } \\
\text { Structure } \\
\text { Types }\end{array}$ & $\begin{array}{c}\text { Page } \\
\text { Number(s) }\end{array}$ \\
\hline Kind & Id & 115 \\
Stubborn & & 290 \\
Sensitive & Ego & 121 \\
Bad-tempered & & $311-312$ \\
\hline Critical & Superego & $88,92-93$ \\
Vindictive & & 91 \\
\hline Honest & & 43 \\
Attentive & & \\
\hline
\end{tabular}

The first focus of this analysis is Fatih's character in the novel Egosentris by Syahid Muhammad. As in one of the quotation marks in the novel describes the kind characteristic of Fatih.

"Tak menghiraukan jawaban Bapak tua itu, Fatih mengeluarkan uang 50 ribu untuk membeli satu bungkus cireng. "Kembaliannya Bapak belikan sayur untuk makan," ucap Fatih sambil tersenyum."
"Regardless of the old man's answer, Fatih spent his 50 thousand to buy a packet of cireng. "Take the change for you to buy vegetables to eat." Fatih said with a smile."

Excerpt 1, p. 115

The excerpt above shows Fatih is a kind person and cares about the old man who sells cireng he met at the intersection. When he saw the old man selling cireng, id encouraged Fatih to do something that would please him. Sigmund Freud explained, it is the basic structure of personality that works according to the principle of pleasure. The purpose is the immediate fulfilment of satisfaction. Therefore, Fatih's ego also encouraged him to give 50 thousand rupiahs to the old man without asking for a change. When Fatih saw the old man was very grateful for the sustenance he had just received, Fatih looked very happy. Here's the following excerpt from the novel.

"Wajah dinginnya hilang, keceriaan dan kelembutan memancar dari wajahnya. Seperti bukan Fatih yang sedari tadi dilihat Saka."

"His cold face disappeared, joy and tenderness radiated from his face. Like he's not Fatih who had been seen by Saka."

Excerpt 2, p. 115

Thus, when referring to the characterization theory based on its role in the storyline, Fatih is a main character. The main character is a character who is prioritized in a novel (Nurgiyantoro, 2007) even in certain novels, the character is constantly present at every event and does not rule out the possibility that can be found on every page. In addition, Fatih is the protagonist. The protagonist is a character who supports stories, usually has a good character and is admired by the reader. The protagonist displays something is in accordance with the views and expectations of the reader. Sensitive naturally can be said to be born and influenced by genes, brain work and psychological reactions of a person. There is also some indication that pschoanalytics concepts of sensitivity and those of attachment theorists relate directly to phenomena (Fonagy, 1999). Fatih's sensitivity can be seen from the excerpt from the dialogue Fatih below.

"Bukan itu, ingat yang jual cireng tadi siang di perempatan? Pas sampai sini, gue Cuma pengin nangis gara-gara lihat mukanya waktu senyum menerima duit gue. Kayak... hah, gue nggak bisa jelasinnya. Pokoknya gue sedih banget, kayak nggak tega kalo harus Cuma mengerti doang dia nanggung hidup yang berat. Di saat yang sama, gue nggak bisa ngebantu apa-apa buat hilangin beban itu."

"Not like that, do you guys remember who sold cireng this afternoon at the intersection? When I got here, I just wanted to cry because I saw his face smiled when he received my money. Like ... hah, I can't explain it. Anyway, I'm really sad, like, if you don't have just to understand that he has a tough life. At the same time, I can't help anything to lose the burden."

Excerpt 3, p. 121 
From Fatih's dialogue with his friend, Saka, it can be explained that Fatih has a high sense of empathy. According to Daniel Goleman in his book, Emotional Intelligence states empathy is the ability to understand the emotions or feelings of others. Fatih's sense of empathy provoked him to be able to feel the happiness who is experienced by the old man as if Fatih could put himself in the same position. Moreover, Stubborn character is also possessed by Fatih. Stubbornness refers to someone who does not want to listen to the advice of others given to him and only concerned with his own affairs. As mentioned from the argument between Fatih and his friend, Saka, below.

"See, ini yang nggak pernah lu sadar! Lu emang nggak pernah minta bantuan sama orang, but someone is trying to care for you! Yet you never appreciate it dan malah seenak jidat."

"See, this is what you never realized! You never asked someone for help, but someone is trying to care for you! Yet you never appreciate it and you just willy-nilly."

Excerpt 4, p. 290

This excerpt illustrates Saka got angry because Fatih kept asking him to debate trivial issues during their vacation in Dieng. Fatih refused to go climbing Mount Prau with Saka and Fana. Fatih's reason made Saka mad at him, and they argued seriously. Saka thought that Fatih never appreciated his efforts to take away Fatih's sadness. Based on characterization theory, unlike a protagonist who shows the good side of the character, Fatih turns into a stubborn and selfish figure. Not all protagonists are always good. Sometimes in certain situations, a character can act as antagonists and cause conflict in a story. The antagonist is a characteristic as an opponent of the story.

"Gue nggak pernah minta juga dipeduliin. Man, kalo lo ngerasa keberatan untuk peduli sama gue, kalo gue cuma jadi beban, coba aja buat nggak peduli kayak yang pernah lu bilang. Simple."

"I also never asked to be cared for. Man, if you feel objected caring about me, if I just become a burden, just try it for not to care like you ever said. Simple."

Excerpt 5, p. 290

Fatih's characteristic was very stubborn. $\mathrm{He}$ is excellent at debating and doesn't want to lose to fight Saka's argument. Id in Fatih encourages him to behave like that because it is a basic, he always wants to win his argument (selfish) and insists on maintaining his opinion.

Fatih is a critical person, as well. He likes to comment on and think about things that bother him like his friends' social judgment on the news was discussed. Here's the narrative below.

"Pertanyaan demi pernyataan mendatangi kepala Fatih secara keroyokan dan membabi buta. Tentang nilai-nilai kemanusiaan yang dia pikir hanya diri sendiri yang memikirkan hal itu. Tentang arogansi-arogansi dalam kebebasan bertindak dan bersuara, yang tidak memedulikan perasaan orang lain. Tentang kebenaran-kebenaran yang diagungkan orang-orang dan berserakan di media sosial."

"Question by question came to Fatih's head in a chaotic and blind manner. About human values that he thought only himself could think about it. About arrogance in freedom of action and voice, which does not concern with other feelings. About the truths that glorified by people and scattered on social media."

Excerpt 6, p. 26

Critical is the ability to analyzing facts, organizing ideas, defending opinions, making comparisons, picturing conclusions, evaluating arguments and solving problems (Chance, 1986). Fatih is a person considering human values today. He gets easily disturbed by people who arbitrarily throwing comments without thinking about people emotional state. Those who casually comment on others' life without knowing their background and are reluctant to think about what is the adverse effects that will be received by the person. The following dialogue will show Fatih commenting critically to Mrs Asni as a lecturer in Mental Health who is discussing a suicide video case which spread on social media.

"Kita perlu bikin solusi yang preventif, misalnya bikin iklan
atau gerakan untuk mengurangi dampak besar dari
kejadian-kejadian yang jarang dipikirkan mereka yang
membagikan video tersebut."
"We need to make preventive solutions, such as making
advertisements or movements to reduce the big impact from
the actions that are rarely realized by those who share the
video."

Excerpt 7, p. 53

Fatih is more focused on providing solutions to video spreader. This proves Fatih can think critically by finding other ways using different perspectives. Fatih doesn't judge or give a suggestion directly to the video spreader and getting punished as heavy as possible. Fatih is looking for a more effective solution. Fatih's ego stimulated him to think sharply in finding a way out of a problem. Ego develops from the $i d$, which is a personality system that applies as an individual influence on the world and performs its functions based on the principle of reality. Revenge is one of the bad characters Fatih has. Revenge can arise due to many factors; one of them is actions that can hurt feelings to end up getting heartache. Like Fatih, he had a grudge since he was mistreated by Sobirin who always humiliated and bullied him when he sold cassava at school. Since his father died and his mother's cosmetics business went bankrupt, Fatih's family started to run a small business of cassava chips.

"Tak lama Fatih keluar dari warung itu. Dia akhirnya bisa pulang dengan tetap dipaksakan tegap. Tebal saku celananya bisa tetap dipertahankan, meski sebagian wajah Fatih sedikit memar. Siku tangan yang tergores dan lutut 
yang berdarah, serta degup jantung yang berdebar diselimuti kancing baju seragamnya yang terlepas."

\begin{abstract}
"Soon Fatih came out from the stall. He was finally able to go home after being forced. The thickness of his pants pocket can be maintained, although Fatih's faces are slightly bruised. Scratched elbows and knees, and pounding heartbeats covered with loose buttons on his uniform."
\end{abstract}

Excerpt 8, p. 88

Fatih was also misleadingly accused of beating Sobirin until he had to deal with the BK teacher at his school. This thing adds more pain to Fatih's heart. Even when he was in high school, Fatih also became ridicule from his friends for being a seller of cassava chips. Here's the following narrative from the novel.

"Meski selama SMA tak pernah lagi ada yang memalaknya. Tapi ejekan tak pernah lepas dari keripik singkong yang melekat pada dirinya. Bahkan seorang teman pernah berkata, bau keringat Fatih mirip singkong yang gosong hanya karena setiap pagi Fatih selalu membantu sang ibu menggoreng keripik singkong."

"Even though during in high school there was never someone else who gave him a break. But ridicule never escapes from the cassava chips that are attached to him. Even a friend once said the smell of Fatih's sweat resembled cassava was charred just because every morning Fatih always helped his mother to frying."

Excerpt 9, p. 92

Seeing the way some people treat Fatih badly, made his grudge pile up, as explained by the following narrative below.

"Hingga dendam itu tak punya lahan untuk dibalaskan. Dendam itu, tumbuh subur dalam dirinya. Disirami oleh hatinya yang pilu. Mengapa teman-temannya harus selalu mengejeknya? Dendam itu masih hidup hingga kini. Mungkin dada Fatih begitu nyaman hingga dendam tak ingin sekali keluar dari dalam sana. Sedang Fatih, tak tahu bagaimana cara mengusirnya."

"Until the grudge has no land to avenge. Revenge thrives in him. Watered by a heart that was sad. Why should his friends always taunt him? Revenge is still alive until now. Maybe Fatih's chest was so comfortable that revenge didn't want to get out of there. Whereas, he doesn't know how to get rid of it."

\section{Excerpt 10, p. 93}

"Dadanya dipenuhi benci saat ini. Pada masa lalunya, pada beberapa rekan Fatih yang tidak disukainya. Benci itu kian meluas, pada kehidupan sosial, pada setiap komentar di media sosial yang pernah dibacanya. Akan semua kekacauan yang dilihatnya, tangannya tak sanggup lagi mengetik jurnal hariannya."

"His chest is filled with hatred right now. In his past, to particular of Fatih's colleagues, he didn't like. The hatred is getting increasingly widespread, in social life, in every comment on social media he has ever read. For all the chaos he saw, his hand could no longer type in his daily journal."

Excerpt 11, p. 212

It can be seen from two narratives which show that Fatih has saved too much heartache for bullying, ridicule and physical assault by the people to him. This causes Fatih's ego work conferring to the principle of reality to bring up the desire to respond to the pain he receives. Fatih is eager to repay his heartache for those who had hurt him. Nevertheless, Fatih also has a bad-tempered characteristic He sometimes cannot control himself when he's angry in certain situations. Here is the following excerpt below.

“BANGSAAAAAAAAAAT!!!” Fatih memberontak, dua sahabatnya kewalahan. Ditendangnya barang-barang yang berada di dekat dapur. Namun dicengkram lagi tubuh itu. Mata Fatih tak ingin sama sekali melihat sosok yang terbungkus kain kafan di tengah kerumunan."

"BASTAAARD!!!" Fatih rebelled, his two friends were overwhelmed to control him. He kicked all the things near the kitchen. But his body is grabbed by them again. Fatih's eyes did not want to at all see the figure wrapped in a shroud in the middle of the crowd."

Excerpt 12, p. 312

According to Sigmund Freud, emotion is one form of id system, which is a negative act. The narrative excerpt above shows that Fatih really cannot control his anger over his mother' leaving, especially the way his mother died is fairly unfair. Fatih routed his sadness, anger, and all his feelings by destroying stuff near him. Anger is a reaction to express resentment in the form of words or actions. Honesty is a characteristic that is in accordance with the heart, always telling the truth and the words do not mischief others. Two years selling cassava chips, his mother always found her money was not always intact, but at that time Fatih's mother knew the reason why their income in selling chips was always less.

"Fatih tengah menyenandungkan perih, saat obat merah mengalir di atas luka tangan dan kakinya. Namun, hatinya senang. Sudah dua tahun Fatih tidak pernah bisa memberi sang ibu kado hadiah ulang tahunnya. Bagi Fatih, uang setoran yang tidak berkurang sedikitpun, bisa menjadi kado sang ibu."

"Fatih was humming when the red medicine flowed over the wounds of his hands and feet. However, he was happy. Fatih has never been able to give his mother a birthday present for two years. For Fatih, the deposit money didn't reduce at all, can be a gift for his mother."

Excerpt 13, p. 91

This characteristic is supported by a superego personality system that reflects social values and makes individuals aware of moral demands. Fatih never took or used the outcomes of selling chips for his own benefit.

Devotion is an act of caring and affection for others that are shown in the form of attitudes or actions. Fatih's 
dedication is seen from his perspective talking about his girlfriend, Viona on the following excerpt below.

\begin{abstract}
"Perempuan dengan masalah di keluarganya membuatku seperti menemukan seseorang untuk ditolong. Aku seperti diberi sebuah ruang akan tanggung jawab untuk membantu seseorang. Sebuah ruang yang menginzinkanku membantu sesuai dengan caraku. Meski tak jarang Viona kerap membuatku kesal. Untungnya, bukan untuk hal-hal seperti yang dikeluhkan Saka."
\end{abstract}

"A girl with problems in their families make me like finding someone to help. I like being given space for responsibility to help someone. A room that allows me to help is in my way. Although Viona often pisses me off. Fortunately, not for things like Saka complained about."

Excerpt 14, p. 43

Superego encouragement makes Fatih respect with Viona's background who has broken home. Fatih as Viona's boyfriend sympathized with Viona as well, he always loves listening to Viona's stories every day and giving her support and advice.

Conflict is an essential element in plot development. Conflict leads to the understanding of something unpleasant who is experienced by the characteristics of the story, if the character has the right to freedom of choice, he/she will not choose the incident to befall him/her (Meredith \& Fitzgerald, 1972:27). Conflict is something dramatic, referring to a fight between two balanced forces and implying actions and retaliatory actions (Wellek \& Warren, 1989:285). The relation of characters and conflicts in a story has a close relationship with the psychology and psychological experience of the characters.

Conflict consists of three types. First, there are conflicts that occur within the character or commonly called psychological conflict. This conflict is experienced by the character is struggling with himself, so he can overcome and determine what he does later. Secondly, the conflict between character and people around them or commonly referred to as social conflict. Third, conflicts between character and nature and are often referred to as physical or element conflict (Sayuti, 2000).

In the novel Egosentris, Fatih's characteristic is kind, honest, sensitive, critical, and caring. From the various types of characteristic, it can cause conflict. For example, Fatih has a critical characteristic, so everything he thinks too seriously can make him depressed. This can be proved that characteristic can influence conflict. The forms of psychological conflict experienced by Fatih include anger, anxiety, fear, remorse, stress, recklessness, and resentment.

Anger is a reaction in the form of speech or action. Psychic conflicts experienced by Fatih are caused by many events that make him sad, depressed, and emotion alternately. Fatih's anger is not enough at all. Fatih's anger provoked once again when he overheard the conversation of his college friends about the news of his mother's death sticking out in the media.

Fortunately, Fatih's friends did not know that the women who were raped were Fatih's mother. Then Fatih who had already harboured anger immediately beat Henri.

\begin{abstract}
"Fatih tak lagi dapat menahan dirinya, ia beranjak. Mengepalkan tangan sekencang-kencangnya, sekeraskerasnya. Seketika kepalan tangan itu menghajar wajah Henri dari belakang. Bertubi-tubi hingga membiarkan Henri melawan balik. Urat-urat tangannya mengencang. Henri yang terjatuh masih terus dipukuli olehnya dengan sangat cepat. Tangannya seperti pompa tinju yang tidak bisa berhenti."

"Fatih could no longer hold himself back, he stood up. Clenching his fists as stiff as possible, as hard as possible. As soon as his fist struck Henri's face from behind. Over and over again, so he did not let Henri fight him back. The veins of his hands tightened. Henri who fell down was still beaten by him very quickly. His hands are like a boxing pump that can't stop."
\end{abstract}

Excerpt 15, p. 327

From the excerpt above, it is clear that Fatih is very hateful and angry when his friends easily talk about and judge his mother at will. Id's encouragement made Fatih want to vent his anger. He immediately hit Henri mercilessly. And regardless of how Henri was battered, Fatih left the place. The ego in Fatih encouraged him to take action to beat Henri so his anger paid off.

Fear was the psychological conflict Fatih felt then. Fatih's fear this time when he saw a line of comments from people about suicides reported online. These comments are like confronting the suicide, but there are still good comments instead. Here's the following narrative from the novel.

"Ketakutan menyelimuti diri Fatih. Kalimat yang dibacanya bergantian saling berteriak dalam dadanya. Jauh lebih kencang dari suara teman-teman di sekitarnya, menggema dan mencabik-cabik nuraninya. Amarah dan ketakutan sedang ricuh, menggelorakan kekacauan."

"Fears overwhelmed Fatih. The words he read alternately shouted in his chest. Much louder than the sounds of friends around him, echoing and tearing his conscience. Anger and fear are muddled, stirring up chaos."

Excerpt 16, p. 128

Fatih is a sensitive characteristic. He has high empathy and can feel what other people feel. Why is it easy for people to throw negative sayings on social media, that's what burdened Fatih's mind. Id in Fatih encourages empathy and pity with suicide because people still continue to talk and blame them. His fear arose because he could put himself in the position of suicide when people commented on what he had done. Nevertheless, his fear returned when he found his mother had to be checked into a psychiatrist because she was depressed. Since the death of his father, the mother has changed dramatically. His mother became 
more moody and noiseless. Fatih is afraid of the social justice that will be received by her mother and himself if everyone knows about the condition of his mother.

"Iya kalian tahu, orang lain? Lu bisa rasain keselnya gimana, saat orang suka asal ngomong kalo orang yang punya gangguan kejiwaan itu berarti gila? Takut gue."

"Yes, you guys know it, but how about the others? You could feel how annoying it is when public like to say people who have psychiatric disorders are crazy? I'm frightened."

Excerpt 17, p. 179

The excerpt above illustrates Fatih's fears and worries about the response of people out there when they learned that his mother was depressed. Fear is a feeling of being uneasy and feeling threatened. The ego in Fatih flared up and scared of people's views about his mother. The next excerpt illustrates Fatih's fear because he does not believe there are more good things out there. Here's the excerpt.

"Hidup udah terlalu nakutin gue, gue udah nggak punya kepercayaan lagi untuk hal-hal baik di luar sana. Gue kesel, sama wartawan. Seneng banget gangguin gue kemarinkemarin. Gue tertekan, orang lagi sedih banget, malah ditanya-ditanya, abis itu disebarin. Gue tahu mereka lagi nyari duit, tapi dengan mengabadikan kesedihan orang lain? Gue nggak paham lagi. Kesel gue."

"Life has been too frightening me. I have no trust in good things out there. I'm upset, with reporters. They seem pleased to disturb me yesterday. I was miserable, I was really sad, they were even asked, after that, they spread it out. I know they are looking for money, but by perpetuating the sadness of others? I don't understand anymore. I'm mad."

\section{Excerpt 18, p. 345-346}

Fatih looks very depressed with all the conditions and situations that force his mind to keep thinking about things disturb his life. The life burden borne by Fatih was too much, and the peak was when he lost his mother. His mother's death invited reporters to get information from Fatih as if they didn't care Fatih was in mourning. Fatih assumes, people only think of themselves.

Regret is a feeling of unhappiness, disappointment and so on for doing something which is not good. The regret felt by Fatih is caused by himself who did not know about the psychological condition of her mother while he himself is a psychology student.

"Ironis, ya. Gue belajar psikologi. Tapi justru kecolongan sama kondisi nyokap gue," lanjut Fatih, isakan itu masih keras tertahan. Tangisnya tak ingin tumpah dengan terlalu jelas. Tangan Fana memeluk tangan kiri Fatih. Mengusapnya perlahan penuh kasih."

"Ironic, right. I study psychology. But I was missed by my mother's condition," Fatih continued, his sob was still hard to hold back. The tears didn't want to spill too visibly. Fana's hand embraced Fatih's left hand. Wipe it slowly loving."
In the narrative above, the conflict experienced by Fatih, he realized that all this time he had not paid enough attention to his mother. When the ego responds to incentives from $i d$ that interrupts the superego, guilt will occur. The superego in Fatih, who had the principle of moral values, encouraged guilt, he regretted it. It was seen that he was holding back tears in the excerpts of the novel indicates that he failed to fulfil his role as a child.

Furthermore, the psychological conflict experienced by Fatih's characteristic is easily depressed. Feeling depressed can lead to stress or depression. This depends on how strong a person is mentally able to control themselves in certain situations. There are many reasons that make a person easily depressed; one of them can be seen from Fatih who experiences many conflicts and problems. Starting from when he get bullying, his academic performance dropped due to the condition of being breadwinner since the death of his father, his mother who was depressed, could not stand the social judgement, and critical thoughts that always encircled in his head. Mandracchia and Pendleton (2015) said that these mental health issues preserve negative effects such as poor academic performance and also problems of health which might they can drop out of college.

"Tangan kanannya mulai menekan bagian bawah ketiak kirinya seperti biasa. Hingga tak tahan lagi, Fatih memasuki kamarnya. Menutup pintu dengan kencang. Di dalam sana, Fatih berharap sesuatu bisa menenangkannya seperti biasa, hingga kelelahan dan akhinya tertidur."

"His right hand began to press the lower part of his left armpit as usual. Until he could not stand it anymore, Fatih entered his room. Close the door tightly. There inside, Fatih hopes something can calm him as usual, until he is exhausted and finally asleep."

Excerpt 20, p. 213

When Fatih felt sad, depressed or insecure, he often pressed the lower part of his left armpit with his right hand. Given that the id works based on the principle of pleasure or comfort, from id appears the ego that makes Fatih tries to avoid all forms of tension or discomfort. In the novel, it also discussed what Fatih did had something to do with psychosomatic symptoms or something related to emotional or mental disorders. Moreover, loneliness is also part of the psychological conflict that felt by Fatih. The feeling ascended when he was chatting with Fana about his mother's condition while enjoying tea and pisang goreng. Their conversation then spread towards the reason why Fatih always loves to write daily journals until the current status of Fatih and Viona's relationship. But in the middle of the conversation, Fana received a call from Zaki. Fana has an appointment to meet with the company's supervisor, where she works on her essay. Fatih felt his time with his friend was never enough. The following are excerpts in the novel. 
"Harapan Fatih untuk tinggal bersama Fana dan Saka adalah agar dia tak merasa kesepian. Namun nyatanya, hidup tak pernah sesuai keinginannya sejak dulu. Hampir seтиa hal. Bagaimanapun, dirinya memaklumi bahwa kedua temannya pun punya kehidupan yang perlu dijalani secara terpisah dengan dirinya."

"Fatih's hope for staying with Fana and Saka is to make him doesn't feel lonely. But in fact, life had never been allowing to his wishes a long time ago. Almost everything. However, he understood that his two friends also had lives that needed to separate from him."

Excerpt 21, p. 212

Loneliness is the result of the lack of an individual's understanding of social relations, a subjective, unpleasant and depressing experience (Peplau and Perlman). Individuals who feel lonely really need other people to communicate. Loneliness is also interpreted as when someone feels no one can understand it well, feels isolated, and does not have anyone to be runaway, when needed or when stressed (Santrock, 2002). The following is a snippet of the narrative shows Fatih feels lonely.

"Fatih tidak membenci mereka karena tidak bisa selalu ada untuknya. Fatih hanya membenci keadaan saat kedua temannya tidak ada disekitarnya, pikirannya akan menggerogotinya hingga titik paling rendah, amarah yang lama dipendam dan kian menumpuk setiap harinya akan membawanya pada pikiran-pikiran abnormal yang tidak diinginkan Fatih."

"Fatih doesn't hate them because they can't always be there for him. Fatih only hates the situation when his two friends are not around him. His mind will gnaw at it to the lowest point, the long-buried anger that accumulates every day will lead him to abnormal thoughts which Fatih doesn't want."

Excerpt 22, p. 212

To get rid of his loneliness, the ego and $i d$ in Fatih made him decide to stay with Fana and Saka. Because Fatih was convinced, only Fana and Saka could understand and accept him. Fatih, who in fact has a critical and broad mindset, is overwhelmed by those things. At times like that, Fatih needs his two friends to be able to listen to his complaints, understand and calm him.

Fatih also has psychological conflicts in the form of anxiety. When he chitchat with his two friends, Saka and Fana, Fatih began to express the anxiety he felt. About the attitude of people who give comments mutually insulting and dropping as an entertaining make him scared. Fatih felt alone because only he could think about it.

"Tahu bahwa Fana akan mengerti dirinya, Fatih semakin mengeluarkan keresahannya. Tentang dirinya yang tak tahu bagaimana cara menerima hal-hal seperti itu. Tentang kepala yang selalu terasa ditusuk-tusuk jarum setiap kali dirinya terjebak dalam keadaan serba salah. Tertekan oleh hal-hal yang semakin membuatnya terpuruk, namun tak tahu bagaimana cara mengatasinya."

\begin{abstract}
"Knowing that Fana will understand him, Fatih gradually expresses his anxiety. About himself who doesn't know how to accept things like that. About his head that always feels pricked every time he is trapped in a state of wrongdoing. Depressed by things that make it worse, but don't know how to deal with it."
\end{abstract}

Excerpt 23, p. 141

The excerpt above clearly shows how worried Fatih is when he faced with social problems that occur around him. Freud was considered to be the first person to talk about concerns. Generally, anxiety is an emotional experience that is not encouraging for someone when they feel afraid or threat from something that cannot be clearly determined (Langgulung, 1986). The ego in Fatih tried to make him unconcerned about the problem, but the $i d$ encouraged Fatih to continue issuing his critical thoughts. Ego tends to face a tension between the demands of the $i d$ and the superego. If these demands are not successfully addressed, the ego is threatened and anxiety arises.

Fatih's dark past sequence turned him into a cold person. He enjoys being alone. Day by day, problem by problem came to Fatih. The climax was when he heard the news about his mother had died unnaturally. Fatih was devastated and went berserk. Even when he was on campus, his ears continued to catch voices as if confronting and blaming his mother. Although the voices will never know what they are talking about is Fatih's mother. Not to mention news hunters who were reluctant to care about his feelings when asked about his late mother. Fatih couldn't stand it. He felt the world was too cruel to be as fragile as himself. He also planned to end his life by climbing Mount Prau and allowing himself died by hypothermia.

\begin{abstract}
"Mungkin, kalo kalian lagi dengerin ini sekarang di kontrakan, kayaknya gue lagi ngedaki Gunung Prau. Nikmatin hutannya sambil nahan dingin sekuat mungkin. Maaf gue harus ke sini tanpa kalian. Biar kalian nggak usah repot, ngurusin mayat gue nanti yang mati gara-gara hipotermia."

"Maybe, if you're listening to this in the rented, it means I'm on my way climbing Mount Prau. Enjoy the forest while keeping the cold as strong as possible. Sorry I have to come here without you guys. So you don't have to bother, take care of my dead body because of hypothermia."
\end{abstract}

Excerpt 24, p. 347

Fatih's adherence is shown by the narrative above. Fatih did not seem to think about the consequences of what he did. Mandracchia and Pendleton (2015) said that mental health is faced by numerous college students and it causes them to get involved in dangerous actions. Id encourages Fatih to desperately climb Mount Prau and want to end his life there. Beforehand, he had recorded his voice using walkman Aiwa that given by his late father. The recording included Fatih's apology for his behavior and his overly critical in responding to a number of things as well as his complaints so far which continued disturbing him. Further, the disappointment in Fatih also arose and it starting from 
seeing people around him like to disfigure one another, about the secret of his father death who had hidden by his mother for years, and so on. The following narration contains the sound of Fatih's recording on his Walkman found by Fana and Saka in their rented room.

\begin{abstract}
"Semakin ke sini, manusia makin ketebak. Besok, mungkin mayat gue udah diturunin dari puncak Gunung Prau. Berita bakal nyebar di semua media sosial. Catatan gi buku gue akan disebarin sama orang-orang yang pengin berbagi, biar beritanya diliat banyak orang. Mungkin mereka mikir, gue pergi sendirian karena depresi... karena kecewa sama banyak hal."

"The more it's here, the more humans can be guessed. Tomorrow, maybe my body has been descended from the summit of Mount Prau. The news will spread on all social media. The notes in my book will be shared by people who want to share it, so the news will be seen by many people. Maybe they thought, I went alone because of depression ... because I was disappointed with many things."
\end{abstract}

\section{Excerpt 25, p. 348}

Sometimes the disappointment is caused by atmosphere and obstacles that are more related to the environment in which the person lives than himself (Sehandi, 2014). Sometimes the disappointment comes from the inability of a person in terms of body, mind or both to achieve his goal or satisfy his motivation. Fatih keeps his disappointment related to the surrounding environment. For example, Fatih was faced with the fact that his parents died. This will cause him to be deterred from getting love from his parents. Fatih's ego encourages it to stick out when he remembers all the problems and conflicts that occur in his life. On the voice recording, Fatih also conveyed several messages in the following below.

\begin{abstract}
"Mungkin, pesen terakhir yang bisa gue bilang ke kalian, do not ever, underestimate someone's pain. Please, kalian nggak tahu gimana rasanya kalo masalah kalian dibecandain orang-orang. Kalian nggak tahu apa yang udah dihadapi sama orang lain di hidupnya, kalian nggak tahu seberat apa mereka berusaha untuk tetep terlihat baik... dukk... zzztt... ckrekk."

"Maybe, the last message I can tell you is, do not ever, underestimate someone's pain. Please, you don't know how it feels if your problem is made fun by people. You don't know what other people have faced in their life, you don't know how hard they try to stay look good ... dukk... zzztt... ckrekk."
\end{abstract}

Excerpt 26, p. 350-351

Id in Fatih stimulates the ego so that he tells during recording how dangerous the effect someone will receive if they accept words that drop mentally, people who ignore someone's pain. The superego, which is based on good values and moral values, makes Fatih say this so there would be no more such things because Fatih had already experienced it and had a negative impact on his mental health and personality. He did not want the same thing happen to his friends or the people around him.
If related to characterization theory, Fatih is a very complex figure. Abrams said that a complex character is a character who can be seen in all aspects of his life, his personality, and identity (Nurgiyantoro, 2007).

From the beginning until the end of the story, Fatih can display various characteristics and behaviors that are even conflicting and unpredictable - seeing the background of Fatih's life and the many conflicts he experienced, making him a figure that cannot be guessed by the reader. Fatih can also be regarded as a developing character. The type of characterization that undergoes changes and development that is in line with the events and grooves contained in the novel.

Fatih actively interacts with his environment which will influence his attitudes, characteristic and behavior. For example, when Fatih lost his mother, Fatih turned out to be colder and love being alone. He also turned into a temperamental person and had difficulty controlling his emotions. The existence of changes that occur outside of him, and the existence of human relations that give each other influence, can touch his psychiatric and cause changes in characteristic, attitudes and his behavior. The last, based on the possibility of reflecting the characteristics of the story of (groups) of humans from real life, Fatih belongs to a typical characteristic. Typical figures are depictions or reflections of people, or groups of people in the real world and more representative (Nurgiyantoro, 2007). For examples such as the excerpt above that shows Fatih trying to convey a moral message to the reader so that they never ignore someone's feelings and are wise in commenting.

\section{Conclusion}

Based on data analysis using Sigmund Freud's psychoanalytic theory and the characterization theory by Nurgiyantoro in novel Egosentris by Syahid Muhammad, there are some findings that this study need to share in this analysis. (1) The characterization of Fatih in the Egosentris novel includes being kind, honest, sensitive, critical, and caring. But in certain situations, Fatih's characteristic seems turns into unpredictable such as being stubborn, vindictive, and bad-tempered. (2) Psychological conflicts that happened to Fatih made his personality change.

The external and internal conflicts, various problems that are experienced directly or inwardly make him turned to be a cold and inclusive person with an up and down mood like a bipolar. Fatih also has a habit of suppressing his left armpit when feeling depressed or insecure, this can be concluded as psychotic symptoms associated with emotional or mental disorders. From Egosentris, it can be told how important it is to be kind in socializing in the real world and social media without having to hurt anyone. In addition, people should know that growing awareness of mental health is very much needed, especially paying attention to the people who are closest to them. 


\section{Acknowledgement}

This research was supported by the BK Foundation Pekanbaru. Therefore, the authors would like to express their sincere gratitude. Any opinions, findings, and conclusions or recommendations expressed in this material are those of the authors and do not necessarily reflect the views of the respected institution.

\section{References}

Bertens, K. (2006). Psikoanalisis Sigmund Freud. Gramedia Pustaka Utama.

Chance, P. (1986). Thinking in the Classroom: A Survey of Programs. Teachers College Press, 1234 Amsterdam Ave., New York, NY 10027.

Darmalia, V., Priyadi, A. T., \& Seli, S. Analisis Psikologi Terhadap Konflik Batin Tokoh Utama Dalam Novel Ayah Karya Andrea Hirata. Jurnal Pendidikan dan Pembelajaran, 6 (1).

Endaswara, S. (2011). Metode Pembelajaran Drama (Apresiasi, Ekspresi, dan Pengkajian). Yogyakarta: Caps.

Fonagy, P. (1999). Points of contact and divergence between psychoanalytic and attachment theories: Is psychoanalytic theory truly different. Psychoanalytic Inquiry, 19(4), 448-480.

Freud, S. (1920). The ego and the id. SE, 19: 1-66.

Freud, S. (1977). Introductory lectures on psychoanalysis. WW Norton \& Company.

Freud, S. (1986). Freud's discovery of psychoanalysis: The politics of hysteria. Ithaca: Cornell University Press.

Hamuddin, B. (2016). Using Content Analysis (CA) in Seeking the Opportunities for Alumni of English Department in Newspapers. ELT-Lectura, 3(1).

Jelínková, E., Šemelák, M., Danišová, N., Waldnerová, J., Juričková, M., \& Ondrušeková, J. (2018). Traumatized selves in Janice Galloway's The Trick Is to Keep Breathing and AL Kennedy's Night Geometry and the Garscadden Trains. Ars Aeterna, 10(2), 1-7.

Langgulung, H. (1986). Teori-Teori Kesehatan Mental. Pustaka Al Husna.

Mandracchia, J. T., \& Pendleton, S. (2015). Understanding college students' problems: Dysfunctional thinking, mental health, and maladaptive behavior. Journal of College Student Retention: Research, Theory \& Practice, 17(2), 226-242.

McLeod, S. A. (2016). Id, ego and superego. Simply Psychology, 3, 1-4.

Nurgiyantoro, B. (2018). Teori pengkajian fiksi. UGM PRESS.Ratna, Nyoman Kutha. 2004. Teori, Metode, dan Teknik Penelitian Sastra. Yogyakarta: Pustaka Pelajar.

Sari, R., Putri, S. E., Herdi, H., \& Hamuddin, B. (2018). Bridging critical discourse analysis in media discourse studies. Indonesian EFL Journal, 4(2), 8089.

Sehandi, Y. (2014). Mengenal 25 Teori Sastra. Yogyakarta: Ombak.Siswandarti. 2009. Teori Pengkajian Fiksi. Yogyakarta: Gajah Mada University Press.

Syafi'i, I. (2018). Karakter Tokoh dalam Cerpen Langit tak Lagi Biru dan Masa Depan Kesunyian Karya Radhar Panca Dahana Imam Safi'i. Buletin Al-Turas, 24(1), 35-50.

Syahid, M. (2018). Egosentris. Yogyakarta: Gradien Mediatama.

Tamir, M., Schwartz, S. H., Oishi, S., \& Kim, M. Y. (2017). The secret to happiness: Feeling good or feeling right?. Journal of Experimental Psychology: General, 146(10),

Tanış, A., \& Cengizhan, L. (2010). Analyzing the novel "to kill a Mockingbird" in literature class. ProcediaSocial and Behavioral Sciences, 2(2), 4387-4391 